\title{
RESPONSIVITAS KEPOLISIAN DALAM PENANGGULANGAN GENG MOTOR DI KECAMATAN SOMBA OPU KABUPATEN GOWA
}

\author{
Alfian', Muhammadiah², Alimuddin Said ${ }^{3}$ \\ 1) Jurusan Ilmu Administrasi Negara Fisipol Unismuh \\ 2) Jurusan Ilmu Administrasi Negara Fisipol Unismuh \\ 3) Jurusan Ilmu Administrasi Negara Fisipol Unismuh
}

\begin{abstract}
The objective of this research is to find out the Police Responsiveness towards the Prevention ofMotorcycle Gangs at SombaOpuDistric of Gowa Regency. The type of this research is a qualitativeresearch with case study by describing the police responsivenesstowards the prevention ofmotorcycle gangs at SombaOpu District. The data collection technique was conducted through interview, observation and documentation. The data were analyzed through some steps such as data collection, data reduction, data display and conclusion. For the data validation, the researcher applied triangulation method such as: resource triangulation, technique triangulation, and time triangulation. The results of the research reveal that the Police responsivenesstowards the prevention of motorcycle gangs with 3 indicators are: 1) responsive, 2) fast, and 3) on target. The police have strongly responded to the public complaints related to the motorcycle gangs,yetit is not quite fast or precise in solving motorcycle gang cases.
\end{abstract}

Key word: Responsiveness, prevention, motorcycle gangs

\begin{abstract}
ABSTRAK
Tujuan Penelitian ini adalah untuk mengetahui bagaimana responsivitas Kepolisian dalam penanggulangan geng motor di Kecamatan Somba Opu Kabupaten Gowa. Jenis penelitian adalah kualitatif dengan menggambarkan responsivitas Kepolisian dalam penanggulangan geng motor di Kecamatan Somba Opu Kabupaten Gowa. Tipe penelitian adalah studi kasus. Dalam pengumpulan data digunakan teknik wawancara, observasi dan dokumentasi. Teknik analisis data menggunakan pengumpulan data, reduksi data, penyajian data dan penarikan kesimpulan. Keabsahan data digunakan triangulasi yaitu triangulasi sumber, triangulasi teknik dan triangulasi waktu. Hasil penelitian menunjukan bahwa responsivitas Kepolisian dalam penanggulangan geng motor dengan indikator 1) Tanggap, 2) Cepat, 3) Tepat. Kepolisian sangat merespon keluhan masyarakat terkait masalah geng motor namun belum begitu cepat maupun tepat dalam menyelesaikan kasus geng motor.
\end{abstract}

Kata kunci : responsivitas, penanggulangan, geng motor 


\section{PENDAHULUAN}

Kabupaten Gowa merupakan salah satu Kabupaten yang ada di Provinsi Sulawesi Selatan yang memiliki 18 Kecamatan satu diantaranya adalah Kecamatan Somba Opu. Ibu Kota Kabupaten ini terletak di Kota Sungguminasa. Padatnya jumlah penduduk dan pesatnya pertumbuhan ternyata menimbulkan masalah yang cukup banyak, bukan hanya masalah kebersihan lingkungan tetapi juga masalah sosial munculnya geng motor yang dapat meresahkan masyarakat.

Geng motor ini sangat liar dan sangat berbahaya karena dengan menggunakan benda tajam untuk melukai korban bahkan melakukan perampokan sehingga banyak orang merasa cemas terutama pada malam hari

Geng motor merupakan sekelompok pemuda atau remaja yang melakukan tindakan atau perbuatan yang dapat meresahkan cenderung melakukan tindakan anarkis. Salah satu munculnya tindakan anarkis kenakalan remaja adalah adanya keyakinan atau perasaan bersama. Keyakinan bersama terbentuk katakanlah, siapa yang cenderung dipersepsi sebagai maling, melakukan balapan liar, menggambar atau melukis pagar rumah maupun dinding rumah masyarakat yang tinggal di Kecamatan Somba Opu.

Faktor penyebab munculnya geng motor adalah faktor pendorong yaitu psikololgi anak muda yang senang bergerombol dan membentuk geng yang memiliki kesamaan hobi. Faktor penarik yaitu ruang atau kanal yang menyalurkan hobi atau aktivitas anak-anak muda tersumbat, sehingga muncul kegiatan yang destruktif dan kontra produktif dengan perkembangan psikologi remaja.

Vakumnya hukum atau
lambatnya respon dari aparat
Kepolisian. Kemunculan geng motor tidak secara tiba-tiba, namun butuh waktu panjang untuk berproses, berkonsolidasi untuk menjadi sebuah kelompok yang eksis. 
Sanrock (dalam kartono 2007:28) menguraikan bahwa kenakalan remaja merupakan kumpulan dari berbagai prilaku remaja yang tidak dapat diterima secara sosial sehingga terjadi tindakan kriminal. Mengenal siapa remaja dan apa problema yang dihadapinya adalah suatu keharusan bagi orang tua. Dengan bakal pengetahuan ini orang tua dapat membimbing anaknya menataki masa-masa krisis tersebut dengan mulus.

Hal ini sangat dirasakan oleh semua karena dibahu remaja masa kini terletak tanggung jawab moral sebagai generasi penerus menggantikan generasi yang ada saat ini. Mereka inilah yang kelak berperan menajdi sumber daya manusia yang tangguh dan berkualitas, menjadi aset Nasional dsn tumpuan harapan bangsa dalam kompetisi global.

Responsivitas yang merupakan salah satu karakteristik dalam memberikan perlindungan kepada masyarakat adalah kemampuan organisasi untuk mengidentifikasi kebutuhan masyarakat, menyusun prioritas kebutuhan, dan mengembangkan kedalam berbagai program pelayanan. Responsivitas mengukur daya tanggap organisasi terhadap harapan, keinginan, dan aspirasi serta tuntutan warga pengguna layanan. Tujuan utama pelayanan publik adalah memenuhi kebutuhan warga pengguna agar dapat memperoleh pelayanan yang diinginkan dan memuaskan, (Dwiyanto, 2005:152).

Responsivitas merupakan tanggung jawab dari sisi yang menerima pelayanan. Oragnisasi publik dilihat dari sikap tanggapannya terhadap sesuatu yang menjadi permasalahan, kebutuhan, keluhan dan aspirasi masyarakat, dalam gambaran kualitas interaksi antara administrasi publik dengan masyarakat.

Responsivitas dapat dilihat dari kebutuhan, masalah, tuntututan dan aspirasi masyarakat dapat dipuaskan dalam bingkai kebijakan, komperhensivitas dan alsebilitas administrasi, terbukanya administrasi terhadap keterlibatan masyarakat dalam proses pembuatan keputusan, 
tersedianya kursus dan penggantian yang mengarah pada efisiensi ekonomi. Dapat dipahami bahwa responsivitas merupakan kemampuan untuk menyediakan apa yang menjadi tuntutan rakyat.

Menurut Tangkilisan, (2005:177) mendefenisikan responsivitas adalah kemampuan birokrasi untuk mengenal kebutuhan masyarakat, menyusun agenda dan prioritas layanan, serta mengembangkan program-program sesuai dengan kebutuhan dan aspirasi masyarakat. Secara singkat dapat dikatakan bahwa responsivitas ini mengukur daya tangap birokrasi terhadap harapan, keinginan dan aspirasi serta tuntutan masyarakat.

Keluhan yang disampaikan oleh masyarakat pengguna jasa merupakan indikator pelayanan yang memperlihatkan bahwa produk pelayanan yang selama ini dihasilkan oleh birokrasi belum dapat memenuhi harapan pengguna layanan, masih tingginya tingkat keluhan yang disampaikan oleh masyarakat pengguna jasa terhadap birokrasi menunjukan bahwa pada satu sisi kualitas produk layanan birokrasi masih dirasakan tidak dapat memenuhi harapan masyarakat pengguna jasa. Pada sisi lain, telah telah tumbuh kesadaran masyarakat pengguna jasa untuk menuntut hakhaknya sebagai konsumen untuk memperoleh pelayanan dengan kualitas terbaik

Menurut Ziethaml, dkk dalam Hardiyansyah, menjabarkan responsivitas menjadi beberapa indikator seperti. Merespon setiap pelanggan/pemohon yang ingin mendapatkan pelayanan indikator ini mencakup sikap dan komunikasi yang baik dari para penyedia layanan. Petugas/aparatur melakukan pelayanan dengan cepat, berkaitan dengan kesigapan dan ketulusan penyedia layanan dalam menjawab pertanyaan dan memenuhi permintaan.

Petugas aparatur melakukan pelayanan dengan tepat yaitu tidak terjadi kesalahan dalam melayani artinya pelayanan diberikan sesuai dengan keinginan masyarakat sehingga tidak ada yang merasa dirugikan atau pelayanan yang 
didapatnya. Petugas/aparatur melakukan pelayanan dengan cermat berarti penyedia layanan harus selalu fokus dan sungguh-sungguh dalam memberikan pelayanan kepada masyarakat.

\section{Petugas/aparatur melakukan} pelayanan dengan waktu tepat yang berarti pelaksana pelayanan kepada masyarakat diselesaikan dalam waktu yang telah ditentukan sehingga dapat memberikan kepastian pelayanan kepada masyarakat. Semua keluhan pelanggan direspon oleh petugas, bahwa setiap penyedia layanan harus mnyediakan akses kepada masyarakat untuk dapat menyampaikan keluhannya dan dapat dicarikan solusi yang terbaik.

Pada dasarnya setiap manusia membutuhkan pelayanan. Bahkan secara ekstrim dapat dikatakan bahwa pelayanan publik tidak dapat dipisahkan dalam kehidupan manusia. Pelayanan adalah setiap kegiatan yang menguntungkan dalam suatu kumpulan atau kesatuan dan menawrakan kepuasan meskipun hasilnya tidak terikat pada suatu produk secara fisik.

Mennurut Sinambela (2010:3) pada dasarnya setiap manusia membutuhkan pelayanan, bahkan secara ekstrim dapat dikatakan bahwa pelayanan tidak dapat dipisahkan dari kehidupan manusia, pelayanan adalah proses pemenuhan kebutuhan melalui aktivitas orang lain yang langsung. Sedangkan Moenir (2006:17) mendefenisikan pelayanan adalah merupakan suatu proses, proses tersebut menghasilkan suatu produk yang berupa pelayanan yang kemudian diberikan kepada pelanggan.

Menurut Paslong (2007:4) mendefenisikan pelayanan adalah aktivitas seseorang, sekelompok atau organisasi baik langsung maupun tidak langsung unuk memenuhi kebutuhan. Sedangkan menurut Kotler dalam Lukman (2008:8) mengemukakan pelayanan adalah setiap kegiatan yang menguntungkan dalam suatu kumpulan atau kesatuan dan menawarkan kepuasan meskipun hasilnya tidak terikat pada suatu produk secara fisik. 
Menurut Djiptono, (2000:40) menyatakan ada dua faktor yang mempengaruhi kualitas pelayanan yaitu respected service dan perceiped service. Apabila jasa yang diterima atau dirasakan (perceived Service) sesuai dengan yang diharapkan, maka kualitas jasa dipersepsikan sebagai kualitas ideal.

Sebaliknya jika jasa yang diterima lebih rendah dari apa yang diharapkan maka kualitas jasa yang diperesepsikan buruk. Baik tidaknya jasa tergantung pada kemampuan penyedia jasa dalam memenuhi harapan pelanggan secara konsisten.

\section{Fungsi Kepolisiam yang} tercantum dalam Undang-Undang Nomor 2 Tahun 2002 tentang Kepolisian Negara Republik Indonesia yakni dalam pasal 2 adalah salah satu fungsi pemerintah negara dibidang terpeliharanya keamanan dan ketertiban masyarakat, penegakkan hukum, perlindungan, pengayoman dan pelayanan kepada masyarakat. Dalam upaya-upaya yang akan dilakukan, Kepolisian berpegang pada tugas dan wewenang polisi yang diatur lebih lanjut dalam

Undang-Undang Nomor 2 Tahun 2002 tentang Kepolisian Negara Republik Indonesia, Menurut pasal 13 tugas pokok Kepolisian Negara Republik Indonesia adalah memelihara keamanan dan ketertiban masyarakat, menegakkan hukum dan memeberikan perlindungan, pengayoman dan pelayanan kepada masyarakat.

Menurut Soedjono Dirjo dalam Sadjijono (2005:52) menyatakan bahwa ketertiban adalah suasana bebas yang terarah, tertuju pada suasana yang didambakan oleh masyarakat yang menjadi tujuan hukum, ketertiban ini adalah cermin adanya patokan, pedoman dan petunjuk bagi individu didalam pergaulan hidupnya, hidup tertib secara individu sebagai landasan terwujudnya tertib masyarakat yang didalamnya terkandung kedamaian dan keadilan.

Keamanan dan ketertiban
masyarakat harus diciptakan,
diupayakan tidak saja oleh pihak
keamanan (polisi, hansip dan
sekuriti) tetapi oleh seluruh unsur
masyarakat harus terlibat. Keamanan


dan ketertiban merupakan dua hal yang berjalan seiring dan selalu saling mendukung dalam hubungan suasana yang nyaman dan tentram (Rahardi, 2007:48).

\section{METODE PENELITIAN}

Penelitian ini menggunakan metode penelitian kualitatif. Untuk kebutuhan pengumpulan data peneliti melakukan pengumpulan data primer yaitu data empiris yang diperoleh dari informan berdasarkan hasil wawancara. Adapun yang menjadi informan pada penelitian ini adalah Kepala Kepolisian Sektor Somba Opu Kabupaten Gowa, Kepala Unit Lalu Lintas Kepolisian Sektor Somba Opu Kabupaten Gowa. Anggota Reskrim Kepolisian Sektor Somba Opu Kabupaten Gowa, Anggota Binmas Polsek Somba Opu Kabupaten Gowa.

Masyarakat yang tinggal di Lingkungan Bonto-Bontoa Kecamatan Somba Opu, Masayarakat yang tinggal di Lingkungan Bonto Ramba Kecamatan Somba Opu, masyarakat yang tinggal di Lingkungan
Katangka dan masyarakat yang tinggal di Lingkungan Ramang Polong.

Data sekunder dalam penelitian ini yaitu data yang dikumpulkan peneliti dari berbagai laporanlaporan atau dokumen-dokumen yang bersifat informasi tertulis digunakan penelitian terkait Responsivitas Kepolisian dalam penanggulangan geng motor di Kecamatan Somba Opu Kabupaten Gowa. Dalam pengumpulan data digunakan teknik wawancara, observasi dan dokumentasi.

Dalam menganalisis data digunakan pengumpulan data, reduksi data, penyajian data, dan penarikan kesimpulan. Sedangkan untuk keabsahan data digunakan tiga triangulasi yaitu triangulasi sumber, triangulasi teknik, dan triangulasi waktu.

\section{HASIL DAN PEMBAHASAN}

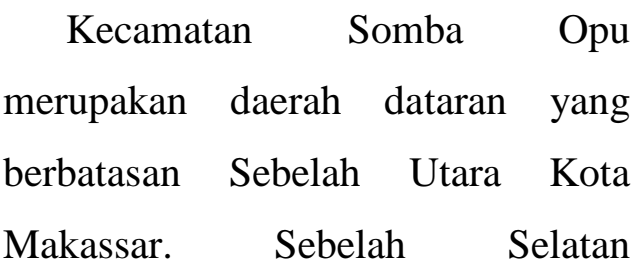
Kecamatan Palangga. Sebelah Barat 
Kecamatan Palangga dan Kota Makassar sedangkan di Seelah Timur berbatasan dengan Kecamatan Bontomarannu, yang memiliki luas wilayah 2.809 hektar. Dengan jumlah kelurahan sebanyak 14 (empat belas) kelurahan dan dibentuk berdasarkan PERDA Nomor 7 Tahun 2005.

Ibukota Kecamatan Somba Opu adalah Kelurahan Sungguminasa dan jumlah penduduk Kecamatan Somba Opu sebesar 151.916 jiwa yang terdiri dari laki-laki sebesar 75.577 jiwa dan perempuan sebesar 76.339 jiwa.

Beberapa fasilitas umum yang terdapat di Kecamatan somba Opu seperti sarana pendidikan antara lain Taman Kanak-Kanak sebanyak 60 buah, kelompok belajar sebanyak 28 buah, Tempat Penitipan Anak sebanyak 3 buah, SPAS sebanyak 14 buah, Sekolah Dasar Negeri sebanyak 14 buah, Sekolah Dasar Impres sebanyak 28 buah, Sekolah Dasar Swasta sebanyak 6 buah, SDLB sebanyak 1 buah.

Sekolah lanjutan Pertama Negeri sebanyak 5 buah, Sekolah Lanjutan
Pertama Swasta sebanyak 12 buah, Sekolah Menengah Umum Negeri sebanyak 3 buah, Sekolah Menengah Umum Swasta sebanyak 10 buah, Sekolah Menengah kejuruan Negeri sebanyak 2 buah, Sekolah Menengah Kejuruan Swasta sebanyak 6 buah, Madrasah Ibtidaiyah sebanyak 2 buah, Madrasah Tsyanawiyah sebanyak 6 buah, Madrasah Aliyah sebanyak 5 buah dan Universitas 1 buah.

Disamping itu terdapat beberapa sarana kesehatan, seperti Rumah Sakit 1 buah, Puskesmas 2 buah, Rumah Bersalin 6 buah, Poliklinik 5 buah, Pustu 3 buah, Praktek Dokter 18, Posyandu 71 buah dan Apotik sebanyak 35 buah. Ada juga tempat Ibadah Mesjid 142 buah, Surau/Mushola 22 buah, Gereja 4 buah dan pasar.

Beberapa kelurahan yang ada di Kecamatan Somba Opu yaitu Kelurahan Sungguminasa, Kelurahan Bonto Bontoa, Kelurahan Batangkaluku, Kelurahan Tompo Balang, Kelurahan Katangka, Kelurahan Pandang-Pandang, Kelurahan Tombolo, Kelurahan 
Kalegowa, Kelurahan Samata, menjalankan fungsi-fungsi kepolisian Kelurahan Romangpolong, tertentu. Beberapa jenis unit yang Kelurahan Paccinongang, Kelurahan berada di bawah jajaran Polsek Tamarunang, Kelurahan Somba Opu antara lain unit reserse Bontoramba, Kelurahan Mawang.

Kesehariannya Polsek Somba Opu dipimpin oleh seorang Kepala Kepolisian Sektor Somba Opu yang berpangkat Komisaris Polisi dan diwakili oleh Wakil Kepala Kepolisian Sektor Somba Opu yang berpangkat Ajun Komisaris Polisi Polsek Somba Opu membawahi beberapa unit yang bertugas untuk kriminal, bagian sium, unit intelkam, unit lalu lintas, unit sabhara, bagian humas, bagian sentra pelayanan polisi terpadu dan provos.

Adapun jenis kejahatan yang terkait geng motor yang terjadi di wilayah hukum Polsek Somba Opu Kabupaten Gowa adalah sebagai berikut:

\section{Tabel 1 : Jenis Kejahatan Terkait Geng Motor.}

\begin{tabular}{|l|l|c|c|c|c|}
\hline No & \multicolumn{1}{|c|}{ Jenis Kasus } & $\mathbf{2 0 1 4}$ & $\mathbf{2 0 1 5}$ & $\mathbf{2 0 1 6}$ & Jumlah \\
\hline 1. & Aniaya Biasa & 21 & 41 & 28 & 90 \\
\hline 2. & Curas & 11 & 17 & 15 & 43 \\
\hline 3. & Curat & 21 & 28 & 31 & 80 \\
\hline 4. & Curanmor & 35 & 33 & 41 & 109 \\
\hline 5. & Pencurian biasa & 37 & 26 & 16 & 79 \\
\hline 6. & Pengeroyokan & 5 & - & - & 5 \\
\hline 7. & Senjata Tajam & 18 & - & 2 & 20 \\
\hline 8. & Pengrusakan & 1 & 2 & 1 & 4 \\
\hline 9. & Jambret & 1 & - & 3 & 4 \\
\hline 10. & Anirat & 1 & 1 & - & 2 \\
\hline 11. & Peras/Ancam & 153 & 148 & 137 & 438 \\
\hline & $\quad$ Jumlah & -2 & - & 2 \\
\hline
\end{tabular}

Sumber : Data Reskrim Kepolisian Sektor Somba Opu, Tahun 2017. 
Berdasarkan tabel diatas dapat diketahui bahwa jenis kejahatan yang ditangani Kepolisian Sektor Somba Opu terkait masalah geng motor dilihat dari kasus kejahatan aniaya biasa pada tahun 2014 sebanyak 21 kasus, pada tahun 2015 mengalami peningkatan menjadi 41 kasus dan tahun 2016 terdapat 28 kasus, sedangkan kasus curas pada tahun 2014 terdapat 11 kasus, pada tahun 2015 mengalami peningkatan terdapat 17 kasus dan pada tahun 2016 terdapat 15 kasus.

Tingkat kejahatan curat pada tahun 2014 terdapat 21 kasus dan pada tahun 2015 meningkat menjadi 28 kasus, pada tahun 2016 terdapat 31 kasus, sedangkan tingkat kejahatan kasus curanmor pada tahun 2014 terdapat 35 kasus, pada tahun 2015 meningkat menjadi 33 kasus dan pada tahun 2016 terdapat 41 kasus, sedangkan tingkat kejahatan kasus pencurian biasa pada tahu 2014 terdapat 37 kasus, pada tahun 2015 menurun menjadi 26 kasus dan pada tahun 2016 terdapat 16 kasus.

Kejahatan kasus pengeroyokan pada tahun 2014 terdapat 5 kasus, sedangkan pada tahun 2015 dan 2016 tidak ada terjadi kasus kejahatan pengeroyokan, sedangkan kasus senjata tajam pada tahun 2014 terdapat 18 kasus dan pada tahun 2015 menurun tidak ada sama sekali kasus kejahatan senjata tajam dan pada tahun 2016 terdapat 2 kasus, sedangkan kasus pengrusakan pada tahun 2014 terdapat terdapat 1 kasus, pada tahun 2015 terdapat 2 kasus dan pada tahun 2016 terdapat terdapat 1 kasus kejahatan pengrusakan.

Kasus jambret pada tahun 2014 terdapat 1 kasus, sepanjang tahun 2015 tidak terjadi kasus jambret dan pada tahun 2016 terdapat 3 kasus jambret sedangkan kasus anirat pada tahun 2014 terdapat 1 kasus, pada tahun 2015 terdapat pula kasus dan sepanjang tahun 2016 tidak terjadi kasus anirat sedangkan kasus peras/ancam pada tahun 2014 terdapat 2 kasus dan pada tahun 2015 dan tahun 2016 tidak ada perbuatan kejahatan peras ancam.

Dari penjelasan tersebut diatas dapat disimpulkan pada tahun 2014 dan tahun 2015 kejahatan geng motor selalu terjadi dan pada tahun 
2016 mengalami penurunan. Jumlah kejahatan terkait masalah geng motor dari tahun 2014 sampai tahun 2016 terdapat 438 kasus yang setiap tahunnya mengalami penurunan dari jumlah kasus pada tahun 2014 terdapat 153 kasus, tahun 2015 terdapat 248 kasus dan pada tahun 2016 terdapat 137 kasus.

Responsivitas Kepolisian dalam penanggulangan geng motor di Kecamatan Somba Opu Kabupaten Gowa dilihat dari 3 indikator yaitu : 1) Respon/tanggap, 2) Cepat, 3) Tepat.

Respon sangat diperlukan dalam pelayanan publik karena hal tersebut merupakan bukti aparat Kepolisian Sektor Somba Opu Kabupaten Gowa untuk menggali kebutuhan masyarakat, menyusun agenda dan prioritas pelayanan serta mengembangkan program-program pelayanan publik sesuai dengan kebutuhan dan aspirasi masyarakat.

Respon kepolisian dalam melayani masyarakat tidak terlepas sikap komunikatif baik yang diberikan aparat kepolisian selaku penyedia layanan merupakan hal penting dalam menanggapi laporan maupun pengaduan masyarakat yang ingin mendapatkan pelayanan.

Kepolisian memberikan sikap komunikatif dalam melayani masyarakat dan bersama-sama masyarakat untuk mencegah perbuatan geng motor, Kepolisian sangat merespon keluhan masyarakat terkait adanya perbuatan geng motor dan mengharapkanadanya informasi atau peran serta dari masyarakat untuk dapat mencegah perbuatan geng motor.

Kepolisian menjalin mitra kerja dengan masyarakat untuk mencegah terjadinya perbuatan geng motor yang dapat meresahkan masayarakat. Kepolisian juga selalu memberikan pesan-pesan ataupun arahan terkait dalam mencegah terjadi geng motor agar terciptanya rasa aman dan tertib.

Kepolisian telah memberikan pelayanan yang baik kepada masyarakat dan menanggapi keluhan masyarakat terkait masalah geng motoryang merupakan tanggungjawab dalam menciptakan 
rasa aman dan tertib di lingkungan masyarakat.

Kepolisian selalu menyampaikan kepada masayarakat agar berhati-hati membawa kendaraaan dan jangan selalu memperlihatkan barangbarang yang berharga pada saat mengendarai sepeda motor, agar tidak menimbulkan kejahatan yang dilakukan oleh geng motor.

Sikap kepolisian dalam menanggapi keluhan masyarakat terkait masalah geng motor merupakan faktor penting dalam terciptanya rasa aman dan tertib di Kecamatan Somba Opu Kabupaten Gowa, dengan demikian masyarakat yang ingin mendapatkan pelayanan

Anggota kepolisian merespon
sesegera mungkin keluhan
masyarakat terkait adanya geng
motor yang dapat meresahkan
masayarakat dengan langsung
mendatangi tempat kejadian setelah
mendapatkan pengaduan dari
masyarakat untuk melakukan
tindakan. Kepolisian bekerja sama
dengan Bhabinsa dan masyarakat
untuk mencegah perbuatan geng

motor yang dapat menggangu keamanan dan ketertiban di lingkugan masayarakat.

Pelayanan yang diberikan kepolisian belum sesuai yang diharapkan oleh masyarakat, kepolisian kurang maksimal dalam menanggapi keluhan masyarakat hendaknya Kepolisian sungguhsungguh dalam penanganan geng motor agar masyarakat tidak selalu cemas terkait masalah geng motor.

Sikap kepolisian dalam merespon keluham masyarakat terkait masalah geng motor sudah sesuai apa yang diharapkan masayarakat dan merasakan lebih aman, anak-anak yang terlibat terkait masalah geng motor sudah berkurang dengan adanya bimbingan dari anggota kepolisian kepada anak-anak untuk tidak terlibat dalam masalah geng motor.

Anggota kepolisian langsung mendatangi tempat kejadian setelah mendapatkan informasi dari masyarakat dan membubarkan aksi geng motor bila di temukan dalam pemeriksaan kendaraan yang tidak 
lengkap maka kepolisian mengambil tindakan dengan cara menilang.

Kecepatan dapat diartikan
sebagai pelayanan yang diberikan
aparatur dengan cepat melayani dan
memenuhi kebutuhan masyarakat
yang ingin mendapatkan pelayanan
dari Kepolisian Sektor Somba Opu,
target waktu pelayanan dapat
diselesaikan dalam waktu yang telah
ditentukan oleh kepolisian.

Kecepatan kepolisian dalam menyelesaikan laporan masyarakat terkait adanya masalah geng motor meliputi dua indikator, kesigapan kepolisian dalam memenuhi permintaan masyarakat, waktu yang dibutuhkan kepolisian menyelesaikan pengaduan masayarakat.

Kepolisian langsung menindak lanjuti pengaduan masyarakat terkait geng motor, dengan cara langsung mendatangi tempat kejadian untuk melakukan tindakan baik itu pemeriksaan maupun penangkapan agar masyarakat tidak merasa resah perbuatan yang dilakukan geng motor, anggota kepolisian cepat mengambil tindakan terkait adanya masalah geng motor, menyampaikan kepada rekan-rekan yang bertugas di lapangan untuk melakukan tindakan atau penangkapan secepat mungkin terkait adanya masalah geng motor yang dapat meresahkan masyarakat, waktu yang dibutuhkan Kepolisian dalam menyelesaikan pengaduan masayarakat adanya masalah geng motor dilihat dari kasus atau masalah yang sedang ditangani.

Kepolisian meminta masayarakat segera menghubungi atau melaporkan jika ada kejadian yang dapat meresahkan masayarakat, maka Kepolisian akan sesegera mungkin turun ke tempat kejadian untuk melakukan tindakan penangkapan maupun penyelidikan.

Tergantung dari tingkat kesulitan masalahnya apakah memerlukan penyelidiakan atau tidak, jika alat bukti tercukupi terkait masalah yang sedang ditindaklanjuti maka langsung diproses sesuai dengan aturan hukum yang berlaku, masyarakat yang mendapatkan pelayanan dari kepolisian sudah sesuai yang diharapkan oleh masyarakat, kepolisian mengambil 
tindakan cepat dalam menanggapi masalah geng motor.

Kecepatan kepolisian dalam mengambil tindakan tidak begitu cepat dan tidak begitu lambat dalam menaggapi keluhan masyarakat, tergantung dari masalah yang dihadapi dalam menyelesaikan kasus geng motor, aparat kepolisian melalui Binmas selalu memeberikan pesan-pesan kepada masyarakat dalam mencegah terjadinya geng motor.

Kepolisian kurang begitu cepat dalam menangani masalah geng motor, tidak membutuhkan waktu yang lama jika aparat kepolisian sungguh- sungguh dalam menanggulangi kejahatan geng motor yang dapat meresahkan masyarakat khusunya pada malam hari, sebab geng motor tidak seperti virus dapat di lokalisir.

Waktu yang dibutuhkan kepolisian untuk mendatangi tempat kejadian perkara untuk melakukan penindakan adanya laporan masayarakat rata - rata 15 sampai dengan 20 menit mengingat arus lalu lintas yang begitu padat dan jarak tempat kejadian perka.

Relatif dilihat dari tingkat masalah yang sedang di tangani. Secepatnya mendatangi tempat kejadian perkara bila mendapatkan laporan dari masyarakat terkait adanya masalah geng motor, anggota kepolisian yang piket baik di penjagaan, reserse maupun intel selalu siap untuk melayani masyarakat.

Ketepatan pelayanan kepolisian diartikan sebagai pelaksana pelayanan kepada masyarakat tidak terjadi kesalahan dalam melakukan tindakan menyelesaikan kasus geng motor di masyarakat sesuai dengan yang diinginkan masyarakat sehingga tidak ada merasa yang dirugikan.

Tindakan yang diambil aparat kepolisian dalam penyelesaian kasus geng motor dilhat dari jenis pelanggarannya, apabila hanya pelanggaran lalulintas maka akan di berikan sangsi tilang, apabila melakukan perbuatan kriminal maka akan diproses sesuai dengan aturan hukum yang berlaku. 
Anggota kepolisian melalui Kantibmas dan Bhabinsa bersama masyarakat selalu melakukan patroli guna untuk mencegah terjadinya perbuatan geng motor yang dapat meresahkan masyarakat.

Penyelesaikan kasus geng motor kepolisian tidak selalu tepat sasaran, dengan adanya pelaku geng motor yang sudah ditindak lanjuti atau ditangkap masyarakat dapat mersakan pelayanan yang baik dari kepolisian, penanganan masalah geng motor hendaknya dilakukan secara terapadu bersama-sama Polsek lain. Dalam melakukan penindakan kepolisian juga tidak selalu tepat sasaran namun tidak dilakukan penindakan atau dilepas kembali.

Standar operasional prosedur merupakan suatu pedoman atau acuan untuk melaksanakan tugas dan fungsi kepolisian dalam melakukan tindakan maupun memberikan pelayanan kepada masyarakat atau aturan tertulis yang membantu untuk mengontrol perilaku anggota kepolisian dalam menyelesaikan masalah di lingkungan masyarakat terkait masalah geng motor.

Bila ditemukan diluar ketentuan sudah masuk pidana maka akan di porses sesuai aturan yang berlaku. Dalam menyelesaikan kasus geng motor kepolisian selalu tepat dalam melakukan penangkapan sesuai SOP.

Begitu mendapat laporan dari masyarakat terkait adanya perbuatan geng motor yang dapat meresahkan masyarakat serta selalu melakukan patroli, kepolisian juga selalu tepat sasaran dalam menindak lanjuti geng motor apa bila tidak ditemukan tindak pidana kepolisian melakukan pembinaan dengan cara memanggil orang tua, mebuat surat pernyataan atau di serahkan ke Dinas Sosial.

Melakukan swiping pada malam hari untuk mencegah terjadinya perbuatan geng motor yang dapat meresahkan masyarakat, dalam melakukan penangkapan aparat Kepolisian selalu tepat sasaran, bila ada yang salah tangkap maka tidak akan diproses, Kepolisian juga bertindak sesuai dengan Standar Operasional Prosedur (SOP) yang 
telah ditentukan agar tidak adanya masyarakat yang merasa dirugikan.

Pelayanan yang diberikan oleh kepolisian bertindak sesuai dengan standar operasional yang telah di tentukan dalam memberikan pelayanan kepada masyarakat, maupun melakukan tindakan baik penangkapan terhadap pelaku kejahatan geng motor maupun pada saat menggelar pemeriksaan kendaraan.

Anggota kepolisian diberikan arahan dari pimpinan sebelum melakukan tindakan peneyelesaian kasus geng motor, agar tidak keluar dari aturan atau standar operasional yang telah ditentukan maupun tidak melanggar hak azasi manusia sehingga masyarakat tidak merasa dirugikan pada saat polisi melakukan tindakan untuk menciptakan rasa aman dan tertib. di lingkungan masyarakat.

\section{KESIMPULAN}

Respon kepolisian adanya keluhan masyarakat masalah geng motor meliputi. Komunikasi kepolisian dalam melayani masyarakat dapat dikatakan cukup baik kepolisian telah memberikan pelayanan yang cukup baik dalam melayani masyarakat yang ingin mendapatkan pelayanan. dan menyelesaikan masalah terakait geng motor yang dapat meresahkan masayarakat.

Sikap kepolisian dalam menaggapi keluhan masyarakat terkait masalah geng motor dapat dikatyakan cukup baik kepolisian merespon dengan baik keluhan masyarakat terkait masalah geng motor yang sudah sesuai apa yang diharapkan oleh masyarakat selaku penerima pelayanan.

Kecepatan kepolisian menyelesaikan kasus geng motor meliputi kesigapan kepolisian dalam memenuhi permintaan masyarakat dapat dikatakan cukup baik kepolisian sesegera mungkin mendatangi tempat kejadian perkara ketika mendapat laporan dari masyarakat adanya kejahatan yang dilakukan oleh geng motor, waktu yang dibutuhkan kepolisian dalam menyelesaikan pengaduan masih belum dikatakan cepat dikarenakan waktu yang dibutuhkan kepolisian 
dalam mendatangi tempat kejadian perkara cukup lama antara 15 sampai 20 menit sehingga dengan mudah pelaku geng motor melarikan diri.

Ketepatan kepolisian mengambil tindakan menyelesaikan kasus geng motor meliputi, kepolisian tepat sasaran dalam mengambil tindakan belum dapat dikatakan maksimal sebab masih adanya kesalahan yang dilakukan dalam melakukan penangkapan walaupun tidak dilakukannya penahanan oleh kepolisian, sehingga masayarakat merasa dirugikan akibat tindakan tresebut.

Standar operasional prosedur yang digunakan kepolisian dapat dikatakan cukup baik, kepolisian menjalankan tugas sesuai aturan yang telah di tentukan, dalam mengambil suatu tindakan anggota kepolisian selalu di berikan arahan dari pimpinan agar tidak keluar dari aturan yang telah ditentukan.

\section{DAFTAR PUSTAKA}

Dwiyanto, Agus, dkk. 2005. Mewujudkan Good
Governance Melalui Pelayanan Publik. Yogyakarta: Pusat Studi Kependidikan dan Kebijakan (PSKK).

Hardiyansyah, 2011. Kualitas Pelayanan Publik. Yogyakarta: Gava Media.

Kartono, K. 2007. Psikologi Anak (Psikologi Perkembangan). Yogyakarta: Gava Media.

Tangkilisan, Hassel Nogi, S. 2005. Manajemen Publik. Jakarta: PT. Grasindo.

Sinambela, Litjan Poltak, dkk. 2010. Reformasi Pelayanan Publik: Teori, Kebijakan, dan Implementasi. Jakarta: Bumi Aksara.

Moenir, A.S. 2006. Manajemen Pelayanan Umum di Indonesia. Jakarta: PT. Bumi Aksara.

Paslong, Harbani. 2007. Teori Administrasi Publik. Bandung: Alfabeta.

Sadjijono, 2005. Fungsi Kepolisian dalam Pelaksanaan Good Governance. Yogyakarta: Laks bang.

Rahardi, Pudi. 2007. Hukum Kepolisian (Profesionalisme Reformasi Polri). Surabaya: Laksbang Meditama.

Tjiptono, Fandy. 2007. Strategi Pemasaran. Edisi Kedua. Yogyakarta: Andi. 